\title{
Ochrobactrum daejeonense sp. nov., a nitrate-reducing bacterium isolated from sludge of a leachate treatment plant
}

Correspondence

Myungjin Lee

mgeneli@nate.com
Sung-Geun Woo, ${ }^{1,2}$ Leonid N. Ten, ${ }^{1}$ Joonhong Park ${ }^{2}$ and Myungjin Lee ${ }^{1}$

${ }^{1}$ Research and Development Division, H-Plus Eco Ltd, BVC 301, KRIBB, Eoeun-dong,

Yuseong-gu, Daejeon 305-333, Republic of Korea

${ }^{2}$ School of Civil and Environmental Engineering, Yonsei University, Seoul 120-749, Republic of Korea

A Gram-reaction-negative, non-spore-forming, rod-shaped, aerobic bacterial strain, designated $\mathrm{MJ} 11^{\top}$, was isolated from sludge of a leachate treatment plant in Daejeon, South Korea, and was characterized taxonomically by using a polyphasic approach. Comparative 16S rRNA gene sequence analysis showed that strain $\mathrm{MJ} 11^{\top}$ belonged to the family Brucellaceae, class Alphaproteobacteria, and was most closely related to Ochrobactrum ciceri $\mathrm{Ca}-34^{\top}$ ( $97.9 \%$ sequence similarity) and Ochrobactrum pituitosum CCUG $50899^{\top}$ (96.4\%). Comparative sequence analyses of the additional phylogenetic marker genes dnaK, groEL and gyrB confirmed the affiliation of strain $\mathrm{MJ} 11^{\top}$ to the genus Ochrobactrum. The $\mathrm{G}+\mathrm{C}$ content of the genomic DNA of strain $\mathrm{MJ} 11^{\top}$ was $59.3 \mathrm{~mol} \%$. The detection of a quinone system with ubiquinone $\mathrm{Q}-10$ as the predominant respiratory lipoquinone, a fatty acid profile with $\mathrm{C}_{18: 1} \omega 7 c(62.6 \%)$ and $\mathrm{C}_{19: 0}$ cyclo $\omega 8 c(14.2 \%)$ as the major components, a polar lipid profile with phosphatidylglycerol, phosphatidylethanolamine, phosphatidylcholine, phosphatidylmonomethylethanolamine, diphosphatidylglycerol and unknown aminolipids AL1 and AL2 as major polar lipids and spermidine and putrescine as the predominant polyamines also supported the affiliation of strain $\mathrm{MJ} 11^{\top}$ to the genus Ochrobactrum. The DNA-DNA relatedness between strain $\mathrm{MJ} 11^{\top}$ and Ochrobactrum ciceri DSM $22292^{\top}$ was $29 \pm 7 \%$, clearly showing that the isolate constitutes a new genospecies. Strain $\mathrm{MJ} 11^{\top}$ could be clearly differentiated from its closest neighbours on the basis of its phenotypic, genotypic and chemotaxonomic features. Therefore, strain $\mathrm{MJ} 11^{\top}$ represents a novel species of the genus Ochrobactrum, for which the name Ochrobactrum daejeonense sp. nov. is proposed. The type strain is $\mathrm{MJ}_{11} 1^{\top}\left(=\mathrm{KCTC} 22458^{\top}=\mathrm{JCM} 16234^{\top}\right)$.
The genus Ochrobactrum, a member of the family Brucellaceae in the class Alphaproteobacteria, was established by Holmes et al. (1988). At the time of writing, the genus Ochrobactrum comprised 16 species with validly published names, including the recently described species

Abbreviations: AL, aminolipid; DPG, diphosphatidylglycerol; HE, hydroxyethyl; PC, phosphatidylcholine; PE, phosphatidylethanolamine; PG, phosphatidylglycerol; PL, phospholipid; PME, phosphatidylmonomethylethanolamine.

The GenBank/EMBL/DDBJ accession number for the 16S rRNA gene sequence of strain $\mathrm{MJ} 11^{\top}$ is HQ171203. The GenBank/EMBL/DDBJ accession numbers for the partial $d n a K$, gyrB and groEL sequences of strains $\mathrm{MJ} 11^{\top}$ and Ochrobactrum ciceri DSM $22292^{\top}$ are HQ285866, $\mathrm{HO} 285868$ and HQ285870, and HQ285867, HQ285869 and HQ285871, respectively.

Two supplementary figures and one supplementary table are available with the online version of this paper.
Ochrobactrum pecoris (Kämpfer et al., 2011). Type strains of species of the genus Ochrobactrum have been recovered from a diverse range of sources, including soil (Lebuhn et al., 2000), plants and their rhizospheres (Trujillo et al., 2005; Tripathi et al., 2006; Zurdo-Piñeiro et al., 2007; Kämpfer et al., 2008; Imran et al., 2010), industrial environments (Kämpfer et al., 2008; Huber et al., 2010), animals (Kämpfer et al., 2003, 2011) and humans (Holmes et al., 1988; Velasco et al., 1998; Teyssier et al., 2007; Kämpfer et al., 2007a). In the present paper, we describe a Gram-reaction-negative, nitrate-reducing bacterial strain, designated $\mathrm{MJ} 11^{\mathrm{T}}$, which was isolated from sludge of a leachate treatment plant. On the basis of 16S rRNA gene sequence data, the strain was found to be a member of the genus Ochrobactrum. Further study of this strain was based on a polyphasic approach that included chemotaxonomic and physiological analyses and DNA-DNA hybridization, 
and confirmed its position as a representative of a novel species within the genus Ochrobactrum.

Strain $\mathrm{MJ} 11^{\mathrm{T}}$ was isolated from sludge of the aerobic treatment tanks of a municipal leachate treatment plant located in Daejeon, South Korea. The sludge sample had a $\mathrm{pH}$ of 6.8 and a total solids content of $35.4 \mathrm{~g} \mathrm{l}^{-1}$. The sludge was resuspended and spread on Luria-Bertani (LB) agar (Difco) plates after being serially diluted with $50 \mathrm{mM}$ phosphate buffer ( $\mathrm{pH} 7.0)$. The plates were incubated at $30{ }^{\circ} \mathrm{C}$ for 2 weeks. Single colonies were purified by transferring them onto fresh plates and incubating under the same conditions. Strain $\mathrm{MJ} 11^{\mathrm{T}}$ was routinely cultured on LB agar at $30{ }^{\circ} \mathrm{C}$ and maintained in a $20 \%(\mathrm{w} / \mathrm{v})$ glycerol suspension at $-70{ }^{\circ} \mathrm{C}$. Ochrobactrum anthropi KCTC $22833^{\mathrm{T}}$, Ochrobactrum ciceri DSM 22292 ${ }^{\mathrm{T}}$, Ochrobactrum intermedium KACC $11952^{\mathrm{T}}$, Ochrobactrum oryzae KACC $12297^{\mathrm{T}}$, Ochrobactrum pituitosum DSM $22207^{\mathrm{T}}$ and Ochrobactrum pseudintermedium KCTC $22760^{\mathrm{T}}$ were used as reference strains in this study.

For phylogenetic analysis of strain $\mathrm{MJ} 11^{\mathrm{T}}$, genomic DNA was extracted by using a commercial genomic DNAextraction kit (Solgent) followed by PCR-mediated amplification of the 16S rRNA gene and sequencing of the purified PCR product, which were carried out according to Kim et al. (2005). The almost full-length sequence of the $16 \mathrm{~S}$ rRNA gene was compiled by using SeqMan software (DNASTAR). The 16S rRNA gene sequences of related taxa were obtained from the GenBank database. Multiple alignments were performed by using the program CLUSTAL_X (Thompson et al., 1997). Gaps were edited in the BioEdit program (Hall, 1999). Evolutionary distances were calculated by using Kimura's two-parameter model (Kimura, 1983). A phylogenetic tree was reconstructed using the neighbour-joining method (Saitou \& Nei, 1987) in the MEGA4 program (Tamura et al., 2007), with bootstrap values based on 1000 replications (Felsenstein, 1985).

The nearly complete 16S rRNA gene sequence of strain $\mathrm{MJ}_{11}{ }^{\mathrm{T}}$ was obtained (1389 bp). The isolate exhibited an elongated 16S rRNA gene sequence characterized by an insertion of $47 \mathrm{nt}$. This insertion has been described previously in the type strains of Ochrobactrum ciceri (Imran et al., 2010) and Ochrobactrum pituitosum (Huber et al., 2010), which are the closest phylogenetic relatives of strain $\mathrm{MJ} 11^{\mathrm{T}}$. In addition, the $47 \mathrm{nt}$ insertion has been reported for some isolates of $O$. intermedium, including strains ADV1-ADV7, ADV9, PR17/sat (Teyssier et al., 2003), CCUG 1838, CCUG 44770 and CCM 7036 (Scholz et al., 2008). As mentioned by Imran et al. (2010), BLAST searches in GenBank using the insertion sequence detected $100 \%$ sequence similarity to the $16 \mathrm{~S}$ rRNA gene sequences of more than 10 partially characterized $O$. tritici isolates (e.g. accession numbers AY972337, AY972330, AY972328), a few isolates of $O$. anthropi and O. intermedium and some uncultured bacterial clones (accession numbers EU769179, EU149209 and DQ917822).
Strain $\mathrm{MJ} 11^{\mathrm{T}}$ showed the highest $16 \mathrm{~S}$ rRNA gene sequence similarity to the type strains of the species Ochrobactrum ciceri $(97.9 \%)$ and Ochrobactrum pituitosum (96.4\%). Sequence similarities $<95 \%$ were found with other recognized species of the family Brucellaceae. When the sequence was corrected for the $47 \mathrm{bp}$ insertion sequence, strain $\mathrm{MJ} 11^{\mathrm{T}}$ shared highest $16 \mathrm{~S}$ rRNA gene sequence similarity with Ochrobactrum intermedium LMG $3301^{\mathrm{T}}$ (97.2\%), Ochrobactrum oryzae MTCC $4195^{\mathrm{T}}(96.5 \%)$ and Ochrobactrum pseudintermedium ADV $31^{\mathrm{T}}$ (96.3\%). The relationship between strain $\mathrm{MJ} 11^{\mathrm{T}}$ and other members of the genus Ochrobactrum was also evident in the neighbourjoining phylogenetic tree (Fig. 1). Recently, sequence analyses of genes encoding the DNA gyrase B subunit (gyrB), chaperonin GroEL ( $g r o E L)$ and the $70 \mathrm{kDa}$ heatshock protein (dnaK) have been applied for the accurate identification of species of the genus Ochrobactrum (Teyssier et al., 2007; Huber et al., 2010). Comparative sequence analyses of these genes were, therefore, performed in the present study. Partial gyrB and groEL sequences of strain $\mathrm{MJ} 11^{\mathrm{T}}$ and Ochrobactrum ciceri DSM $22292^{\mathrm{T}}$ were analysed according to Huber et al. (2010) using the primer pairs GyrB_f/GyrB_r and GroEL_f/GroEL_r, respectively. Partial $d n a K$ sequences of strain $\mathrm{MJ} 11^{\mathrm{T}}$ and $O$. ciceri DSM $22292^{\mathrm{T}}$ were obtained using primers $289 \mathrm{f}$ and $1142 \mathrm{r}$ as described previously (Teyssier et al., 2007). Phylogenetic trees based on dnaK, groEL and gyrB gene sequences were reconstructed using the neighbour-joining method (Supplementary Fig. S1, available in IJSEM Online). The dnaK, groEL and $g y r B$ trees revealed only moderate consistency with the tree topology based on 16S rRNA gene sequences and showed marked differences in the branching order. In the gyrB gene sequence-based tree, strain $\mathrm{MJ} 11^{\mathrm{T}}$ grouped with type strain of $O$. anthropi and in the $d n a K$ - and groEL gene sequence-based trees, strain MJ11 ${ }^{\mathrm{T}}$ occupied a distinct phylogenetic position within the genus Ochrobactrum (Supplementary Fig. S1). Discrepancies may be explained by different datasets (not all sequences of all species were available), different sequence lengths of genes or differences in the apparent rate of evolution of protein-encoding genes with respect to the $16 \mathrm{~S}$ rRNA gene. Nevertheless, each of these trees supported the status of strain $\mathrm{MJ} 11^{\mathrm{T}}$ as a separate species and its affiliation to the genus Ochrobactrum. The maximum similarity levels were $93.9 \%$ with $O$. cicero, based on groEL gene sequences; $91.5 \%$ with $O$. ciceri and O. pseudintermedium, based on dnaK gene sequences; and $89.8 \%$ with $O$. ciceri and $O$. intermedium, based on gyrB gene sequences. The presence of the $r e c A$ gene, another alternative phylogenetic marker, was determined using the primer pairs recA-BrucOchro-f/recA-BrucOchro-r, recA-PsOchro-f/recAPsOchro-r and recA-wob-f/recA-wob-r, as described by Scholz et al. $(2006,2008)$. O. intermedium KACC $11952^{\mathrm{T}}$ was used as a positive control. However, all attempts to amplify a recA gene fragment from the DNA of strain MJ11 ${ }^{\mathrm{T}}$ using these primer sets were unsuccessful, suggesting that this strain was closely related to O. ciceri $\mathrm{Ca}-34^{\mathrm{T}}$ (Imran et al., 2010) but differed markedly from strains of $O$. 


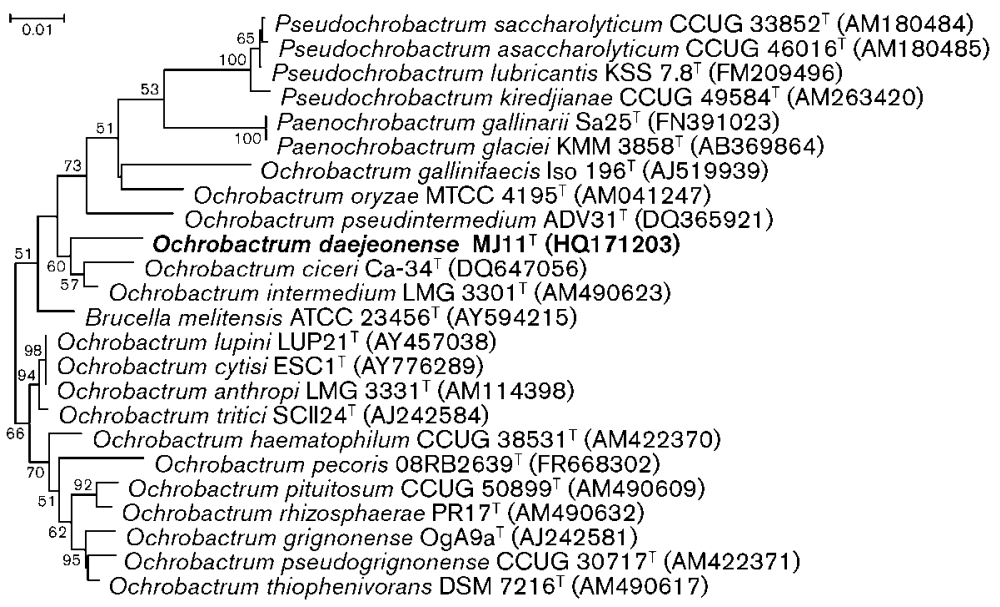

Fig. 1. Neighbour-joining tree, based on $16 \mathrm{~S}$ rRNA gene sequences, showing the phylogenetic position of strain $\mathrm{MJ} 11^{\top}$ among recognized members of the genus Ochrobactrum and other related species of the family Bruce/laceae. Bootstrap values $>50 \%$, based on 1000 replications, are shown at branch points. Bradyrhizobium japonicum ATCC $10324^{\top}$ (accession no. U69638) was used as an outgroup (not shown). Bar, 0.01 substitutions per nucleotide position.

pituitosum (Huber et al., 2010), O. anthropi and $O$. intermedium (Scholz et al., 2006, 2008). These data indicated that strain $\mathrm{MJ} 11^{\mathrm{T}}$ could be clearly separated from other members of the genus Ochrobactrum with the exception of O. ciceri. To differentiate strain $\mathrm{MJ} 11^{\mathrm{T}}$ from its closest phylogenetic relative, DNA-DNA hybridization experiments were performed.

The Gram reaction was determined by using a Gram-stain kit (Difco) according to the manufacturer's instructions. Cell morphology and motility were observed under a Nikon light microscope $(\times 1000$ magnification $)$ using exponential- and stationary-phase cultures grown at $30{ }^{\circ} \mathrm{C}$ on $\mathrm{R} 2 \mathrm{~A}$ agar and by using the hanging drop technique. Tests for anaerobic growth, catalase and oxidase activities and nitrate and nitrite reduction were performed as described previously (Ten et al., 2006). Assimilation of single carbon sources, enzyme activities, acid production from substrates and other physiological characteristics were determined using API ID $32 \mathrm{GN}$ (at $30{ }^{\circ} \mathrm{C}$ for $48 \mathrm{~h}$ ), API ZYM (at $30{ }^{\circ} \mathrm{C}$ for $4 \mathrm{~h}$ ), API $20 \mathrm{NE}$ (at $30{ }^{\circ} \mathrm{C}$ for $48 \mathrm{~h}$ ) and API $50 \mathrm{CHB}$ (at $30{ }^{\circ} \mathrm{C}$ for $48 \mathrm{~h}$ ) galleries (bioMérieux) and Biolog GN MicroPlate panels (at $30{ }^{\circ} \mathrm{C}$ for $48 \mathrm{~h}$ ) according to the manufacturers' instructions. Nitrogen-fixing ability was determined as previously reported by Im et al. (2006). The primer system PolF-PolR (Poly et al., 2001) was used to amplify the nifH gene according to the methods described by Im et al. (2004). Biochemical tests for hydrolysis of aesculin, casein, gelatin and starch, arginine dihydrolase and chitinase activities, Voges-Proskauer reaction and hydrogen sulfide production were performed as described by Tindall et al. (2007). Tests for the degradation of DNA, using DNase agar (Scharlau) with DNase activity detected by flooding plates with $1 \mathrm{M} \mathrm{HCl}$ (Collins \& Lyne, 1984), and tests for the degradation of xylan and hydroxyethyl (HE)-cellulose (Ten et al., 2004) were performed and evaluated after 7 days. Growth at 10, $15,20,25,30,34,37$ and $42{ }^{\circ} \mathrm{C}$ was assessed on R2A agar, nutrient agar, LB agar, trypticase soy agar (TSA; Difco) and MacConkey agar after 5 days of incubation. Growth at
$\mathrm{pH}$ 5.0-10.0 (at intervals of $0.5 \mathrm{pH}$ units) was evaluated in LB broth at $30{ }^{\circ} \mathrm{C}$.

Cells of strain $\mathrm{MJ}^{1} 1^{\mathrm{T}}$ were Gram-reaction-negative, aerobic, non-spore-forming rods $(0.7-0.8 \times 0.8-0.9 \mu \mathrm{m})$ that exhibited motility at exponential phase but no motility at stationary phase. Colonies grown on LB agar plates for 2 days at $30{ }^{\circ} \mathrm{C}$ were $2-5 \mathrm{~mm}$ in diameter, slightly convex, shiny, viscous and pale yellow. On LB agar, good growth was observed between $25-30{ }^{\circ} \mathrm{C}$ and weak growth was observed at 20 and $34{ }^{\circ} \mathrm{C}$. Strain $\mathrm{MJ} 11^{\mathrm{T}}$ was not able to grow at 15 or $37^{\circ} \mathrm{C}$. Good growth also occurred on R2A agar, nutrient agar, TSA and MacConkey agar at $25-30{ }^{\circ} \mathrm{C}$. Strain $\mathrm{MJ} 11^{\mathrm{T}}$ reduced nitrate to nitrite but did not reduce nitrite to nitrogen gas. The isolate did not grow in a nitrogen-free liquid medium, suggesting that it may not have a nitrogen-fixing ability. Attempts to amplify the nifH gene (encoding the iron protein of nitrogenase) failed with the specific primers used (Poly et al., 2001). These findings are consistent with results obtained with $O$. ciceri $\mathrm{Ca}-34^{\mathrm{T}}$ (Imran et al., 2010). Phenotypic and chemotaxonomic characteristics that differentiate strain $\mathrm{MJ} 11^{\mathrm{T}}$ from closely related members of the genus Ochrobactrum are listed in Table 1. In contrast to the reference strains, the novel isolate was positive for assimilation of itaconate, 3- and 4hydroxybenzoate, phenylacetate, salicin, suberate and valerate as well as acid production from gluconate, 5ketogluconate and methyl $\beta$-D-xylopyranoside. The isolate was also negative for utilization of L-rhamnose. In addition, strain $\mathrm{MJ} 11^{\mathrm{T}}$ could be differentiated from the reference strains and other recognized members of the genus Ochrobactrum based on the results of Biolog GN MicroPlate tests (Supplementary Table S1).

For the measurement of chromosomal DNA G+C content, the genomic DNA of the strain was extracted and purified as described by Moore \& Dowhan (1995) and degraded enzymically into nucleosides. The DNA G $+\mathrm{C}$ content was then determined as described by Mesbah et al. (1989) using reversed-phase HPLC. Cell biomass for isoprenoid quinone analysis was obtained from cultures 
Table 1. Differential phenotypic characteristics between strain $\mathrm{MJ} 11^{\top}$ and closely related type strains in the genus Ochrobactrum

Strains: $1, \mathrm{MJ}_{11}^{\mathrm{T}} ; 2$, O. ciceri DSM $22292^{\mathrm{T}} ; 3$, O. pituitosum DSM $22207^{\mathrm{T}}$; 4, O. intermedium KACC $11952^{\mathrm{T}}$; 5, O. anthropi KCTC $22833^{\mathrm{T}}$; 6, O. oryzae KACC $12297^{\mathrm{T}}$; 7, O. pseudintermedium KCTC $22760^{\mathrm{T}}$. All data are from the present study. All strains were positive for nitrate reduction and were negative for indole and hydrogen sulfide production and lysine decarboxylase and ornithine decarboxylase activities. In API ID 32 GN, API 20 NE (assimilation of carbon sources), API ZYM and API 50 CHB tests, all strains showed identical biochemical characteristics except for those substrates indicated here and in the species description. +, Positive; -, negative; w, weakly positive.

\begin{tabular}{|c|c|c|c|c|c|c|c|}
\hline Characteristic & 1 & 2 & 3 & 4 & 5 & 6 & 7 \\
\hline \multicolumn{8}{|l|}{ Growth at: } \\
\hline $20{ }^{\circ} \mathrm{C}$ & + & - & + & + & + & + & - \\
\hline $37{ }^{\circ} \mathrm{C}$ & - & + & - & + & + & + & + \\
\hline Aesculin and gelatin hydrolysis & - & + & - & - & - & - & - \\
\hline Arginine dihydrolase & + & + & - & - & - & - & - \\
\hline Voges-Proskauer reaction & + & + & + & - & - & + & - \\
\hline \multicolumn{8}{|l|}{$\begin{array}{l}\text { Enzyme activities } \\
\text { (API ZYM and API } 20 \text { E): }\end{array}$} \\
\hline Alkaline phosphatase & + & + & + & - & - & $\mathrm{w}$ & - \\
\hline $\begin{array}{l}\text { Cystine arylamidase, } \\
\alpha \text {-glucosidase }\end{array}$ & + & + & + & - & - & - & - \\
\hline Esterase lipase (C8) & - & + & + & + & - & + & + \\
\hline$\beta$-Galactosidase, $\beta$-glucosidase & - & + & - & - & - & - & - \\
\hline $\begin{array}{l}\text { Naphthol-AS-BI- } \\
\text { phosphohydrolase }\end{array}$ & + & + & + & + & - & - & + \\
\hline Tryptophan deaminase & + & + & + & - & - & + & - \\
\hline Valine a & - & + & - & - & - & - & - \\
\hline Urease & - & + & - & + & + & + & - \\
\hline \multicolumn{8}{|l|}{$\begin{array}{l}\text { Assimilation of } \\
\text { (API ID } 32 \mathrm{GN} \text { and API } 20 \mathrm{NE} \text { ): }\end{array}$} \\
\hline Acetate & + & + & - & + & + & + & + \\
\hline Caprate & + & - & - & + & + & - & + \\
\hline Citrate & - & + & + & + & + & - & - \\
\hline Glucona & + & + & - & $\mathrm{w}$ & + & + & $\mathrm{w}$ \\
\hline Inositol & + & + & + & - & + & - & + \\
\hline $\begin{array}{l}\text { Itaconate, } 3 \text { - or } \\
\text { 4-hydroxybenzoate, salicin, } \\
\text { phenylacetate, suberate, valerate }\end{array}$ & + & - & - & - & - & - & - \\
\hline DL-3-Hydroxybutyrate & + & + & $\mathrm{w}$ & - & + & + & - \\
\hline D-Mannitol & + & + & + & - & + & + & - \\
\hline Propionate & + & + & - & + & + & + & - \\
\hline L-Rhamnose & - & + & + & + & + & + & + \\
\hline D-Ribose & + & - & $\mathrm{w}$ & - & + & - & - \\
\hline D-Sorbitol & + & + & + & - & + & + & + \\
\hline \multicolumn{8}{|l|}{$\begin{array}{l}\text { Acid production from } \\
\text { (API } 50 \mathrm{CHB} \text { ): }\end{array}$} \\
\hline $\mathrm{N}$-Acetylglucosamine, la & + & + & - & - & - & + & + \\
\hline Adonitol, maltose & + & + & - & + & + & + & + \\
\hline $\begin{array}{l}\text { Aesculin, inositol, gentiobiose, } \\
\text { sucrose and xylitol }\end{array}$ & + & + & - & + & - & + & + \\
\hline L-Arabinose & + & + & + & - & - & + & + \\
\hline D-Arabitol, dulcitol & + & - & - & + & - & + & + \\
\hline
\end{tabular}

Table 1. cont.

\begin{tabular}{|lccccccc|}
\hline Characteristic & $\mathbf{1}$ & $\mathbf{2}$ & $\mathbf{3}$ & $\mathbf{4}$ & $\mathbf{5}$ & $\mathbf{6}$ & $\mathbf{7}$ \\
\hline Arbutin, cellobiose, salicin & + & + & - & - & - & - & - \\
D-Galactose & + & - & + & + & + & + & + \\
Gluconate, 5-ketogluconate, & + & - & - & - & - & - & - \\
methyl $\beta$-D-xylopyranoside & & & & & & & \\
D-Glucose & + & + & + & - & - & + & - \\
Glycerol & + & + & + & - & + & - & - \\
Glycogen, starch & - & + & - & - & - & - & + \\
Inulin, raffinose & - & - & - & - & - & - & + \\
D-Mannitol & + & - & - & - & - & + & - \\
D-Mannose, trehalose, & + & + & - & - & - & + & - \\
methyl $\alpha$-D-glucopyranoside & & & & & & & \\
Melibiose & - & + & - & - & - & + & + \\
Methyl $\alpha$-D-mannopyranoside & - & + & + & - & - & - & - \\
L-Rhamnose & - & + & - & + & - & + & + \\
D-Ribose & + & + & + & + & + & + & - \\
Sorbitol & - & + & + & - & - & + & + \\
D-Xylose & + & + & + & + & - & + & + \\
& & & & & & &
\end{tabular}

grown in LB broth for 2 days at $30{ }^{\circ} \mathrm{C}$. Quinones were extracted, fractionated and analysed by HPLC as described previously (Hiraishi et al., 1996). Cellular fatty acids were analysed using cultures grown on nutrient agar for $48 \mathrm{~h}$ at $30{ }^{\circ} \mathrm{C}$. The cellular fatty acids were saponified, methylated and extracted according to the protocol of the Sherlock Microbial Identification System (MIDI). Fatty acid methyl esters were then analysed by GC (model 6890; Hewlett Packard) using the Microbial Identification software package (Sasser, 1990). Polyamines were extracted and analysed according to the methods of Busse \& Auling (1988) and Schenkel et al. (1995). Polar lipids were extracted using the procedure described by Minnikin et al. (1984) and identified by two-dimensional TLC followed by spraying with appropriate detection reagents as described previously (Lee et al., 2008).

The cellular fatty acid composition of strain $\mathrm{MJ} 11^{\mathrm{T}}$ was similar to that of the type strains of six reference species of the genus Ochrobactrum, containing a large amount of $\mathrm{C}_{18: 1} \omega 7 c$, moderate amounts of $\mathrm{C}_{19: 0}$ cyclo $\omega 8 c, \mathrm{C}_{16: 0}$ and $\mathrm{C}_{18: 0}$ and a small amount of $\mathrm{C}_{18: 1} 2-\mathrm{OH}$ (Table 2). Some quantitative differences were found between the proportions of these components in strain $\mathrm{MJ} 11^{\mathrm{T}}$ and the six reference strains. In particular, the summed proportions of the major fatty acids $\mathrm{C}_{18: 1} \omega 7 c$ and $\mathrm{C}_{19: 0}$ cyclo $\omega 8 c$, which was used to compare fatty acid profiles between strains of the genus Ochrobactrum (Huber et al., 2010), was smaller in strain $\mathrm{MJ11}^{\mathrm{T}}(74.8 \%)$ than was found in its closest neighbours, O. ciceri DSM $22292^{\mathrm{T}}(82.9 \%)$ and O. pituitosum $22207^{\mathrm{T}}(77.2 \%)$. Apart from these differences, strain $\mathrm{MJ} 11^{\mathrm{T}}$ differed from its closest neighbours mainly by the absence of $\mathrm{C}_{17: 0}$ cyclo. Two-dimensional TLC analysis of polar lipids extracted from strain $\mathrm{MJ1}^{\mathrm{T}}$ (Supplementary Fig. S2) showed that the isolate contained the characteristic unknown aminolipid AL2, which was detected in polar lipid 
Table 2. Fatty acid compositions of strain $\mathrm{MJ} 11^{\top}$ and closely related type strains in the genus Ochrobactrum

Strains: $1, \mathrm{MJ}_{11}^{\mathrm{T}} ; 2$, O. ciceri DSM $22292^{\mathrm{T}}$; 3, O. pituitosum DSM $22207^{\mathrm{T}}$; 4, O. intermedium KACC $11952^{\mathrm{T}}$; 5, O. anthropi KCTC $22833^{\mathrm{T}}$; 6, O. oryzae KACC $12297^{\mathrm{T}}$; 7, O. pseudintermedium KCTC $22760^{\mathrm{T}}$. All data are from the present study. All strains were grown on nutrient agar for $48 \mathrm{~h}$ at $30{ }^{\circ} \mathrm{C}$ prior to fatty acid analysis. Values are percentages of total fatty acids. -, Not detected.

\begin{tabular}{|lccccccc|}
\hline Fatty acid & $\mathbf{1}$ & $\mathbf{2}$ & $\mathbf{3}$ & $\mathbf{4}$ & $\mathbf{5}$ & $\mathbf{6}$ & $\mathbf{7}$ \\
\hline $\mathrm{C}_{10: 0}$ & - & - & - & 1.1 & - & - & - \\
$\mathrm{C}_{16: 0}$ & 11.5 & 5.3 & 6.9 & 6.1 & 9.6 & 10.4 & 12.4 \\
$\mathrm{C}_{17: 0}$ & 0.8 & 1.2 & 2.4 & 2.1 & 0.9 & 0.2 & 1.4 \\
$\mathrm{C}_{18: 0}$ & 8.5 & 6.7 & 9.1 & 6.5 & 10.7 & 9.7 & 4.5 \\
$\mathrm{C}_{17: 0}$ cyclo & - & 0.4 & 0.5 & - & 0.6 & - & 1.1 \\
$\mathrm{C}_{19: 0}$ cyclo $\omega 8 c$ & 14.2 & 15.1 & 42.1 & 28.3 & 27.3 & 11.4 & 33.0 \\
$\mathrm{C}_{12: 1}$ at $11-12$ & - & - & - & 3.8 & - & - & - \\
$\mathrm{C}_{18: 1} \omega 7 c$ & 62.6 & 67.8 & 35.1 & 50.3 & 50.6 & 66.7 & 40.8 \\
$\mathrm{C}_{18: 1}$ 2-OH & 1.4 & 3.5 & 1.7 & 1.8 & 0.3 & - & 3.9 \\
$\mathrm{C}_{18: 1}$ 3-OH & - & - & 0.3 & - & - & - & - \\
Summed feature $3^{*}$ & 1.0 & - & 1.9 & - & - & 1.6 & 2.9 \\
& & & & & & & \\
\hline
\end{tabular}

${ }^{*}$ Summed features represent groups of two or three fatty acids that could not be separated by GLC with the MIDI system. Summed feature 3 comprises $\mathrm{C}_{16: 1} \omega 7 c$ and/or iso- $\mathrm{C}_{15: 0} 2-\mathrm{OH}$.

extracts of other members of the genus Ochrobactrum but was not produced by representatives of the closely related genus Pseudochrobactrum (Kämpfer et al., 2006, 2007b). The overall polar lipid pattern of strain $\mathrm{MJ} 11^{\mathrm{T}}$ corresponded to that described for the genus Ochrobactrum (Kämpfer et al., 2003, 2007a, 2008; Teyssier et al., 2007), and comprised large amounts of phosphatidylglycerol (PG), phosphatidylethanolamine (PE), phosphatidylcholine (PC) and phosphatidylmonomethylethanolamine (PME) as well as moderate amounts of diphosphatidylglycerol (DPG) and unknown aminolipid AL1. Minor unknown aminolipids AL3 and AL4, phospholipids PL2 and PL4 and polar lipid L2 were also detected and have previously been found in other members of the genus Ochrobactrum (Kämpfer et al., 2007a; Huber et al., 2010). The polyamine pattern of strain $\mathrm{MJ} 11^{\mathrm{T}}$, with putrescine and spermidine as predominant compounds and sym-homospermidine as a minor component, was in agreement with polyamine compositions reported for other members of the genus Ochrobactrum (Kämpfer et al., 2007a, 2008). Analysis of the respiratory lipoquinones of strain $\mathrm{MJ} 11^{\mathrm{T}}$ revealed ubiquinone Q-10 as the predominant compound with trace amounts of Q-9. The DNA G+C content of the novel isolate was $59.3 \mathrm{~mol} \%$, which is slightly higher than values reported for other type strains in the genus Ochrobactrum (54.5-59.0 mol\%) (Lebuhn et al., 2000; Teyssier et al., 2007). However, the value still lies within the range recommended for members of the same genus and therefore should be taken into account in the range of $\mathrm{G}+\mathrm{C}$ contents of members of the genus Ochrobactrum.
DNA-DNA hybridizations were performed fluorometrically according to the method of Ezaki et al. (1989), using photobiotin-labelled DNA probes (Sigma) and microdilution wells (Greiner), with five replications for each sample. The highest and lowest values obtained for each sample were excluded and the means of the remaining three values were quoted as the DNA-DNA hybridization values. SD was also calculated based on these three values. Strain MJ11 ${ }^{\mathrm{T}}$ exhibited relatively low levels of DNA-DNA relatedness with respect to Ochrobactrum ciceri DSM $22292^{\mathrm{T}}(29 \pm 7 \%)$, indicating that they are not related at the species level (Wayne et al., 1987; Stackebrandt \& Goebel, 1994). These results are also in agreement with the recommendation that the 16S rRNA gene sequence similarity threshold be increased from $97 \%$ to $98.7-99 \%$ when determining the uniqueness of a new strain (Stackebrandt \& Ebers, 2006).

The phenotypic and phylogenetic data presented here indicate that strain $\mathrm{MJ} 11^{\mathrm{T}}$ belongs to the genus Ochrobactrum. The phylogenetic distinctiveness, together with the DNA-DNA hybridization data, confirmed that this isolate represents a species that is distinct from recognized species of the genus Ochrobactrum. Strain $\mathrm{MJ} 11^{\mathrm{T}}$ can also be differentiated from its closest phylogenetic relatives based on several phenotypic characteristics (Table 1, Supplementary Table S1). Therefore, on the basis of the data presented here, strain $\mathrm{MJ} 11^{\mathrm{T}}$ represents a novel species of the genus Ochrobactrum, for which the name Ochrobactrum daejeonense sp. nov. is proposed.

\section{Description of Ochrobactrum daejeonense sp. nov.}

Ochrobactrum daejeonense (dae.jeon.en'se. N.L. fem. adj. daejeonense pertaining to Daejeon, a city in South Korea, from where the type strain was isolated).

Cells are Gram-reaction-negative, aerobic, non-spore-forming rods. The $\mathrm{pH}$ range for growth is $\mathrm{pH} 6.0-8.0$, with an optimum of $\mathrm{pH}$ 7.0. Aesculin, casein, chitin, DNA, HE-cellulose, gelatin, starch and xylan are not hydrolysed. The results of tests for carbon source utilization (API ID 32 GN and API $20 \mathrm{NE}$ ), enzyme activities (API ZYM and API $20 \mathrm{E})$ and acid production (API $50 \mathrm{CHB}$ ) are reported in Table 1. N-Acetylglucosamine, L-alanine, L-arabinose, L-fucose, D-glucose, L-histidine, 2-ketogluconate, lactate, malate, maltose, D-mannose, L-proline, L-serine and sucrose are utilized for growth but adipate, glycogen, 5-ketogluconate, malonate and melibiose are not utilized. Positive for acid phosphatase, esterase (C4), leucine arylamidase and trypsin activities but negative for $N$-acetyl- $\beta$-glucosaminidase, $\alpha$ chymotrypsin, $\alpha$-fucosidase, $\alpha$-galactosidase, $\beta$-glucuronidase, lipase (C14), lysine decarboxylase, $\alpha$-mannosidase and ornithine decarboxylase activities. Acid is produced without gas from D-arabinose, erythritol, D-fructose, D- and L-fucose, D-lyxose, D-tagatose, turanose and L-xylose but not from amygdalin, L-arabitol, 2-ketogluconate, melezitose or Lsorbose. Ubiquinone Q-10 is the predominant respiratory lipoquinone. The major fatty acids are $\mathrm{C}_{18: 1} \omega 7 c, \mathrm{C}_{19: 0}$ cyclo 
$\omega 8 c, \mathrm{C}_{16: 0}$ and $\mathrm{C}_{18: 0}$. The major polar lipids are PG, PE, PC, PME, DPG and two unknown AL. The major respiratory quinone is ubiquinone Q-10 with a trace amount of Q-9. The major polyamines are putrescine and spermidine and the minor polyamine is sym-homospermidine.

The type strain, MJ11 ${ }^{\mathrm{T}}\left(=\mathrm{KCTC} 22458^{\mathrm{T}}=\mathrm{JCM} 16234^{\mathrm{T}}\right)$, was isolated from sludge of the aerobic treatment tanks of a municipal leachate treatment plant located in Daejeon, South Korea. The DNA G + C content of the type strain is $59.3 \mathrm{~mol} \%$.

\section{Acknowledgements}

This work was supported by the GAIA Project (173-101-034), Ministry of Environment, Republic of Korea, and by the Korea Brain Pool Program of 2011 (grant 111S-4-5-0032).

\section{References}

Busse, J. \& Auling, G. (1988). Polyamine pattern as a chemotaxonomic marker within the Proteobacteria. Syst Appl Microbiol 11, 1-8.

Collins, C. H. \& Lyne, P. M. (1984). Microbiological Methods, 5th edn. London: Butterworth.

Ezaki, T., Hashimoto, Y. \& Yabuuchi, E. (1989). Fluorometric deoxyribonucleic acid-deoxyribonucleic acid hybridization in microdilution wells as an alternative to membrane filter hybridization in which radioisotopes are used to determine genetic relatedness among bacterial strains. Int J Syst Evol Microbiol 39, 224-229.

Felsenstein, J. (1985). Confidence limits on phylogenies: an approach using the bootstrap. Evolution 39, 783-791.

Hall, T. A. (1999). BioEdit: a user-friendly biological sequence alignment editor and analysis program for Windows 95/98/NT. Nucleic Acids Symp Ser 41, 95-98.

Hiraishi, A., Ueda, Y., Ishihara, J. \& Mori, T. (1996). Comparative lipoquinone analysis of influent sewage and activated sludge by highperformance liquid chromatography and photodiode array detection. J Gen Appl Microbiol 42, 457-469.

Holmes, B., Popoff, M., Kiredjian, M. \& Kersters, K. (1988). Ochrobactrum anthropi gen. nov., sp. nov. from human clinical specimens and previously known as group Vd. Int J Syst Bacteriol 38, 406-416.

Huber, B., Scholz, H. C., Kämpfer, P., Falsen, E., Langer, S. \& Busse, H.-J. (2010). Ochrobactrum pituitosum sp. nov., isolated from an industrial environment. Int J Syst Evol Microbiol 60, 321-326.

Im, W.-T., Bae, H.-S., Yokota, A. \& Lee, S. T. (2004). Herbaspirillum chlorophenolicum sp. nov., a 4-chlorophenol-degrading bacterium. Int J Syst Evol Microbiol 54, 851-855.

Im, W.-T., Kim, S.-H., Kim, M. K., Ten, L. N. \& Lee, S. T. (2006). Pleomorphomonas koreensis sp. nov., a nitrogen-fixing species in the order Rhizobiales. Int J Syst Evol Microbiol 56, 1663-1666.

Imran, A., Hafeez, F. Y., Frühling, A., Schumann, P., Malik, K. A. \& Stackebrandt, E. (2010). Ochrobactrum ciceri sp. nov., isolated from nodules of Cicer arietinum. Int J Syst Evol Microbiol 60, 1548-1553.

Kämpfer, P., Buczolits, S., Albrecht, A., Busse, H.-J. \& Stackebrandt, E. (2003). Towards a standardized format for the description of a novel species (of an established genus): Ochrobactrum gallinifaecis sp. nov. Int J Syst Evol Microbiol 53, 893-896.

Kämpfer, P., Rosselló-Mora, R., Scholz, H. C., Welinder-Olsson, C., Falsen, E. \& Busse, H. J. (2006). Description of Pseudochrobactrum gen. nov., with the two species Pseudochrobactrum asaccharolyticum sp. nov. and Pseudochrobactrum saccharolyticum sp. nov. Int J Syst Evol Microbiol 56, 1823-1829.

Kämpfer, P., Scholz, H. C., Huber, B., Falsen, E. \& Busse, H. J. (2007a). Ochrobactrum haematophilum sp. nov. and Ochrobactrum pseudogrignonense sp. nov., isolated from human clinical specimens. Int J Syst Evol Microbiol 57, 2513-2518.

Kämpfer, P., Scholz, H., Huber, B., Thummes, K., Busse, H.-J., Maas, E. W. \& Falsen, E. (2007b). Description of Pseudochrobactrum kiredjianiae sp. nov. Int J Syst Evol Microbiol 57, 755-760.

Kämpfer, P., Sessitsch, A., Schloter, M., Huber, B., Busse, H.-J. \& Scholz, H. C. (2008). Ochrobactrum rhizosphaerae sp. nov. and Ochrobactrum thiophenivorans sp. nov., isolated from the environment. Int J Syst Evol Microbiol 58, 1426-1431.

Kämpfer, P., Huber, B., Busse, H.-J., Scholz, H. C., Tomaso, H., Hotzel, H. \& Melzer, F. (2011). Ochrobactrum pecoris sp. nov., isolated from farm animals. Int J Syst Evol Microbiol 61, 2278-2283.

Kim, M. K., Im, W.-T., Ohta, H., Lee, M. \& Lee, S.-T. (2005). Sphingopyxis granuli sp. nov., a $\beta$-glucosidase-producing bacterium in the family Sphingomonadaceae in $\alpha-4$ subclass of the Proteobacteria. J Microbiol 43, 152-157.

Kimura, M. (1983). The Neutral Theory of Molecular Evolution. Cambridge: Cambridge University Press.

Lebuhn, M., Achouak, W., Schloter, M., Berge, O., Meier, H., Barakat, M., Hartmann, A. \& Heulin, T. (2000). Taxonomic characterization of Ochrobactrum sp. isolates from soil samples and wheat roots, and description of Ochrobactrum tritici sp. nov. and Ochrobactrum grignonense sp. nov. Int J Syst Evol Microbiol 50, 2207-2223.

Lee, M., Ten, L. N., Lee, H. W., Oh, H. W., Im, W. T. \& Lee, S.-T. (2008). Sphingopyxis ginsengisoli sp. nov., isolated from soil of a ginseng field in South Korea. Int J Syst Evol Microbiol 58, 2342-2347.

Mesbah, M., Premachandran, U. \& Whitman, W. B. (1989). Precise measurement of the $\mathrm{G}+\mathrm{C}$ content of deoxyribonucleic acid by highperformance liquid chromatography. Int J Syst Bacteriol 39, 159-167.

Minnikin, D. E., O’Donnell, A. G., Goodfellow, M., Alderson, G., Athalye, M., Schaal, A. \& Parlett, J. H. (1984). An integrated procedure for the extraction of bacterial isoprenoid quinones and polar lipids. J Microbiol Methods 2, 233-241.

Moore, D. D. \& Dowhan, D. (1995). Preparation and analysis of DNA. In Current Protocols in Molecular Biology, pp. 2-11. Edited by F. W. Ausubel, R. Brent, R. E. Kingston, D. D. Moore, J. G. Seidman, J. A. Smith \& K. Struhl. New York: Wiley.

Poly, F., Monrozier, L. J. \& Bally, R. (2001). Improvement in the RFLP procedure for studying the diversity of nifH genes in communities of nitrogen fixers in soil. Res Microbiol 152, 95-103.

Saitou, N. \& Nei, M. (1987). The neighbor-joining method: a new method for reconstructing phylogenetic trees. Mol Biol Evol 4, 406425.

Sasser, M. (1990). Identification of bacteria through fatty acid analysis. In Methods in Phytobacteriology, pp. 199-204. Edited by Z. Klement, K. Rudolph \& D. C. Sands. Budapest: Akademiai Kaido.

Schenkel, E., Berlaimont, V., Dubois, J., Helson-Cambier, M. \& Hanocq, M. (1995). Improved high-performance liquid chromatographic method for the determination of polyamines as their benzoylated derivatives: application to P388 cancer cells. J Chromatogr B Biomed Appl 668, 189-197.

Scholz, H. C., Tomaso, H., Al Dahouk, S. A., Witte, A., Schloter, M., Kämpfer, P., Falsen, E. \& Neubauer, H. (2006). Genotyping of Ochrobactrum anthropi by recA-based comparative sequence, PCRRFLP, and 16S rRNA gene analysis. FEMS Microbiol Lett 257, 7-16.

Scholz, H. C., Al Dahouk, S., Tomaso, H., Neubauer, H., Witte, A., Schloter, M., Kämpfer, P., Falsen, E., Pfeffer, M. \& Engel, M. (2008). 
Genetic diversity and phylogenetic relationships of bacteria belonging to the Ochrobactrum-Brucella group by recA and 16S rRNA genebased comparative sequence analysis. Syst Appl Microbiol 31, 1-16.

Stackebrandt, E. \& Ebers, J. (2006). Taxonomic parameters revisited: tarnished gold standards. Microbiol Today 33, 152-155.

Stackebrandt, E. \& Goebel, B. M. (1994). Taxonomic note: a place for DNA-DNA reassociation and $16 \mathrm{~S}$ rRNA sequence analysis in the present species definition in bacteriology. Int J Syst Bacteriol 44, 846849.

Tamura, K., Dudley, J., Nei, M. \& Kumar, S. (2007). MEGA4: molecular evolutionary genetic analysis (MEGA) software version 4.0. Mol Biol Evol 24, 1596-1599.

Ten, L. N., Im, W.-T., Kim, M.-K., Kang, M.-S. \& Lee, S.-T. (2004). Development of a plate technique for screening of polysaccharidedegrading microorganisms by using a mixture of insoluble chromogenic substrates. J Microbiol Methods 56, 375-382.

Ten, L. N., Baek, S.-H., Im, W.-T., Liu, Q.-M., Aslam, Z. \& Lee, S.-T. (2006). Bacillus panaciterrae sp. nov., isolated from soil of a ginseng field. Int J Syst Evol Microbiol 56, 2861-2866.

Teyssier, C., Marchandin, H., Siméon De Buochberg, M., Ramuz, M. \& Jumas-Bilak, E. (2003). Atypical 16S rRNA gene copies in Ochrobactrum intermedium strains reveal a large genomic rearrangement by recombination between rrn copies. J Bacteriol 185, 29012909.

Teyssier, C., Marchandin, H., Jean-Pierre, H., Masnou, A., Dusart, G. \& Jumas-Bilak, E. (2007). Ochrobactrum pseudintermedium sp. nov., a novel member of the family Brucellaceae, isolated from human clinical samples. Int J Syst Evol Microbiol 57, 1007-1013.

Thompson, J. D., Gibson, T. J., Plewniak, F., Jeanmougin, F. \& Higgins, D. G. (1997). The CLUSTAL_X windows interface: flexible strategies for multiple sequence alignment aided by quality analysis tools. Nucleic Acids Res 25, 4876-4882.

Tindall, J. B., Sikorski, J., Simbert, A. R. \& Krieg, R. N. (2007). Phenotypic characterization and the principles of comparative systematics. In Methods for General and Molecular Microbiology, 3rd edn, pp. 330-393. Edited by C. A. Reddy, T. J. Beveridge, J. A. Breznak, G. A. Marzluf, T. M. Schmidt \& L. R. Snyder. Washington, DC: American Society for Microbiology.

Tripathi, A. K., Verma, S. C., Chowdhury, S. P., Lebuhn, M., Gattinger, A. \& Schloter, M. (2006). Ochrobactrum oryzae sp. nov., an endophytic bacterial species isolated from deep-water rice in India. Int J Syst Evol Microbiol 56, 1677-1680.

Trujillo, M. E., Willems, A., Abril, A., Planchuelo, A. M., Rivas, R., Ludeña, D., Mateos, P. F., Martínez-Molina, E. \& Velázquez, E. (2005). Nodulation of Lupinus albus by strains of Ochrobactrum lupini sp. nov. Appl Environ Microbiol 71, 1318-1327.

Velasco, J., Romero, C., López-Goñi, I., Leiva, J., Díaz, R. \& Moriyón, I. (1998). Evaluation of the relatedness of Brucella spp. and Ochrobactrum anthropi and description of Ochrobactrum intermedium sp. nov., a new species with a closer relationship to Brucella spp. Int $J$ Syst Bacteriol 48, 759-768.

Wayne, L. G., Brenner, D. J., Colwell, R. R., Grimont, P. A. D., Kandler, O., Krichevsky, M. I., Moore, L. H., Moore, W. E. C., Murray, R. G. E. \& other authors (1987). International Committee on Systematic Bacteriology. Report of the ad hoc committee on reconciliation of approaches to bacterial systematics. Int J Syst Bacteriol 37, 463-464.

Zurdo-Piñeiro, J. L., Rivas, R., Trujillo, M. E., Vizcaíno, N., Carrasco, J. A., Chamber, M., Palomares, A., Mateos, P. F., Martínez-Molina, E. \& Velázquez, E. (2007). Ochrobactrum cytisi sp. nov., isolated from nodules of Cytisus scoparius in Spain. Int J Syst Evol Microbiol 57, 784788. 